\title{
Lignin and Cellulose Changes of Betung Bamboo (Dendrocalamus asper) Pretreated Microwave Heating
}

\author{
Widya Fatriasari ${ }^{\# *}$, Wasrin Syafii ${ }^{*}$, Nyoman Wistara ${ }^{*}$, Khaswar Syamsu ${ }^{1}$,Bambang Prasetya ${ }^{2}$

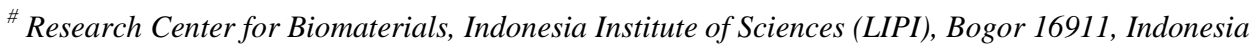 \\ E-mail: widya.fatriasari@biomaterial.lipi.go.id
}

* Department of Forest Product Technology, Faculty of Forestry, Bogor Agricultural University, Bogor 16001, Indonesia E-mail:wasrinsy@indo.net.id; nyomanwis@gmail.com

${ }^{1}$ Department of Agro-Industrial Technology, Faculty of Agricultural Engineering and Technology, Bogor Agricultural University, Bogor 16002, Indonesia

E-mail:khaswars@yahoo.com

${ }^{2}$ National Standardization Agency, Manggala Wanabakti Building, Jakarta, Indonesia

E-mail:bambangpras@yahoo.com

\begin{abstract}
This study highlighted the effect of microwave pretreatment on betung bamboo on the chemical structural and morphological changes. The hydrothermal condition was performed in varying power loading (330, 550, and $770 \mathrm{~W})$ and microwave irradition time (5-12.5 min). FTIR spectroscopy, X-Ray diffraction and SEM-EDS analysis were utilized to confirm the characteristic changes after pretreatment. The results showed that the severe pretreatment condition tended to increase the carbohydrate losses. From FTIR spectra, microwave pretreatment tended to decrease absorbancy of functional group bands. After microwave pretreatment for $12.5 \mathrm{~min}(770 \mathrm{~W})$, the band around $1736 \mathrm{~cm}^{-1}(\mathrm{C}=\mathrm{O}$ in xylan) disappeared in the samples. The syringil propane unit was lower than that of guaiacyl lignin under microwave pretreatment. The disruption of the structure of the cell wall increased the accessibility of cellulase to lignocellulose. Except microwaving for $5 \mathrm{~min}(330 \mathrm{~W})$, the microwave heating caused carbon and oxygen increasing compared to untreated samples. The increase in crystallinity index of pretreated bamboo suggested the selective degradation of amorphous components.
\end{abstract}

Keywords - Microwave Pretreatment; Betung Bamboo; Structural Changes; Morphological Changes.

\section{INTRODUCTION}

Selecting feedstock with high accessible cellulose is key factor to access low cost bioethanol production. Bamboos, perennial grasses of graminae family, include in non woody materials which can grow on poor nutrient land and varied climatic, easy to manage and harvest, fast growth, efficient photosynthesis, high biomass production as well make them a prospective candidate for bioenergy crops [1],[2],[3]. The biomass production of bamboo was higher than the other energy crops such as poplar, switch grass, miscanthus, common reed, and bagasse [4],[5]. These plants have wide area commercial utilization such as food source, pulp and paper, reinceforce fiber, construction, methane, lactic acid and bioenergy feedstock as a novel purpose in recent year. In addition, $1 \%$ of world's forest area (37 million hectares) is bamboo plants [3], and 5\% of them grow in Indonesia with 160 species [6].

To facilitate easily hydrolyzed of lignocellulosic materials by cellulase enzyme, pretreatment is required to break down the recalcitrance structure of biomass [7],[8]. Lignin and crystalline structure of lignocellulosic materials are the most important limitation factors in the bioethanol conversion process of biomass. Any attempts have been done to improve the substrate digestibility to enzyme penetration and one of the attractive environmental friendly-pretreatment methods is microwave pretreatment. The rapid, selective and volumetric heating of polar part covering substrate creating hot spot with inhomogeneous materials lead to open biomass structure and improve the surface area accessibility and pore size [10],[11],[12]. This treatment are also facilitate the lignin degradation, hemicellulose loss, cellulose 
ultrastructure disruption to enhance enzymatic susceptibility of lignocellulosic materials [11],[13],[14],[15].

Microwave pretreatment combined with any chemicals such as alkaline, hydrogen peroxide in various lignocelulosic materials had been conducted in woody and non woody materials e.g. wheat straw [11],[16], sugarcane bagasse [15], [17], switchgrass and bermuda grass [18], rice straw [15],[19],[20],[21],[22], corn stover [23], rice hull [15] and softwood [24]. The extensive studies in microwave pretreatment indicated that the removal of hemicellulose and lignin of pretreated substrate contributed hydrolysis substrate easily to improve fermentable sugar yield. The microwaveassisted alkaline pretreatment of bamboo prior to hydrolyze into fermentable sugar has been conducted by Nomanbhay et al. [13] which reported reducing sugar enhancement about 5.8 fold after this treatment. However, utilization chemicals in microwave pretreatment have potential side effects that are harmful to the environment, thus require neutralization phase before enzymatic hydrolysis. Therefore, this research is approach using microwave heating without chemical for shortening the neutralization step.

From viewpoint the choosing of environmental friendly pretreatment, microwave pretreatment on bamboo is included in this category. Moreover, a detail study of the structural changes after microwave pretreatment in water medium of bamboo affected the substrate digestibility has been not reported in previous study. The evaluation on the effect of various power loading and irradiation time on the characteristic changes will become the basis for determining the selected pretreatment for subsequent step.

\section{MATERIAL AND METHODS}

\section{A. Material}

This study used fresh and barkless 2 year-old bamboo betung (Dendrocalamus asper) harvested from bamboo garden of Research Center for Biomaterials LIPI Cibinong, Indonesia as samples. For obtaining bamboo powder size of 40-60 mesh, the bamboo was processed by drum chipper, ring flaker, hammermil and disk mill.

\section{B. Microwave Pretreatment}

The pretreatment used oven microwave SHARP P-360J (S) set at frequency of $2450 \mathrm{MHz}$ and power output of 1100 Wt. As much as $1 \mathrm{~g}$ of oven dried sample was inserted into the teflon tube (vessel), then added destilled water of $30 \mathrm{~mL}$ to reach solid and solution ratio of 1:30 (w/v). Subsequently, the samples were stirred for $20 \mathrm{~min}$ on the stirer plate and then irradiated at $330 \mathrm{~W}, 550 \mathrm{~W}$, and $770 \mathrm{~W}$ of power loading for 5-12.5 min. The slurry was immediately ice water cooled for 15-20 $\mathrm{min}$ and filtered to separate solid residue out.

\section{Morphological, Cellulose and Lignin Characteristic Changes \\ 1) Chemical Component Determination}

The moisture content (TAPPI T12 os-75) of orgininal and pretreated samples was measured before ethanol-benzene (1:2) extraction. The measurement of ash content (TAPPI T 15 os-58) was performed on the samples. Free extractive samples was then determined the acid-insoluble lignin content (TAPPI T13 os-54), holocellulose (TAPPI T9m-54), and alpha cellulose (Mokushitsu Kagaku Jiken Manual 2000). The weight loss calculation followed Pandey and Pitman [25].

\section{2) X-Ray Diffraction (XRD) of Pretreated Bamboo}

The crystallinity index was measured based on diffraction intensity data of X-ray Diffraction (XRD) analysis.The analysis condition used a diffractometer with $\mathrm{Cu} \mathrm{K}_{\alpha}$ radiation $(0.15406 \mathrm{~nm})$ at $40 \mathrm{kV}$ and $30 \mathrm{~mA}$ (Shimadzu XRD-700 MaximaX series). The samples (40-60 mesh) were placed in holder glass, analyzed at room temperature, scanned and the intensity was recorded in 2 theta ranges from 10 to $40^{\circ}$ in $2^{\circ}$ per min. The crystallinity index of each sample was expressed using the formulation of Zao et al. [26] and Foscher et al. [27].

\section{3) Determination of Cellulose Allomorph Structure}

Crystalline structure (monoclinic and triclinic) of cellulose was determined by z-Discriminate function developed by Wada et al. [28]. Separating cellulose $\mathrm{I} \alpha$ and $\mathrm{I}_{\beta}$ was builted up by d-spaces (two equatorial d-spacing: 0.59$0.62\left(\mathrm{~d}_{1}\right)$ and $\left.0.52-0.55 \mathrm{~nm}\left(\mathrm{~d}_{2}\right)\right)$. Value of $\mathrm{z}>0$ indicated the type of bacteria algae (I $\alpha$, rich triclinic structure) and $\mathrm{z}<0$ indicated the type of cotton and flax (predominantly $I_{\beta}$ structure/monoclinic).

\section{4) Crystallite Size of Cellulose}

Formulation of Ahtee et al. [29] was used to estimate the crystalline area from (101), (10-1), (002), (040) lattice planes based on the diffraction pattern of XRD analysis.

\section{5) Morphological Characterization and Element Analysis}

Morphological analysis of original and pretreated bamboo was examined through scanning electron microscopy (SEM) JEOUL/EO. Bamboo samples were mounted on stub using sputter canter and then scanned at $15 \mathrm{kV}$ with $10 \mathrm{~mm}$ of working distance to capture images under SEM with 10.000 $\mathrm{x}$ of magnification. EDX (Energy Dispersive X-ray Spectroscopy) was used to determine the percentage of type and element content of the sample. Sample's electron scattering of x-rays was captured by the EDX (detector and mapped in the element form based on the received energy difference.

\section{6) FTIR Analysis}

FTIR (Fourier Transform Infrared Spectrometry) analysis was performed to detect functional group changes and observed biodegradation pattern of microwave-pretreated bamboo. FTIR analysis was carried out using FT IR ABB MB 3000 with detector at $16 \mathrm{~cm}^{-1}$ resolution and 5 scans per sample. An amount of $4 \mathrm{mg}$ of dried samples with $200 \mathrm{mg}$ of $\mathrm{KBr}$ (spectroscopic grade) was mixed in a mortar, sealed and then pressed to produce a pellet to be analyzed. Infrared spectrum patterns (peak height and area) of the spectra were recorded with absorption mode in the range of 4000-500 cm${ }^{1}$ using Horizon MB software. The relative intensity changes of band as the characteristic of carbohydrates and lignin would be analyzed by the method of Pandey and Pitman [25]. 


\section{Statistical Analysis}

All the experiments were conducted in triplicate and the data of chemical component changes and losses were presented as mean \pm standard deviation

\section{RESULTS AND DISCUSSION}

\section{A. Effect on Chemical Composition of Pretreated Bamboo}

As a chemical component of cell wall in the lignocellulosic materials, hollocellulose consisted by hemicellulose (branched polymer) and cellulose (linier polymer) is sugar source which can be then hydrolyzed to fermentable sugar. However, this part is sealed lignin polymer causing resistant to degrade into sugar monomer. The microwave irradiation in varied condition facilitate the surface area improvement, substrate softening, pore swelling by removal amorphous parts (lignin and hemicellulose) and cell wall disruption [9]. The thermal pretreatment can cause side effect such as the weight loss of the pretreated bamboo. In general, the increasing of power loading and irradiation time caused a higher weight loss. The weight loss during pretreatment might be affected by deconstruction of carbohydrate-lignin complex as result of the partial removal of lignin and hemicellulose accessing the disruption of the hydrogen bond between cellulose [30].
The power loading and irradiation time in microwave pretreatment are two important parameters affecting the structural changes of lignocellulosic changes of bamboo. The chemical component changes of bamboo after pretreatment were demonstrated in Table 1. The increasing of power loading tended to increase of cellulose contents of pretreated bamboo. It was suggested with irradiation in high microwave power loading allows greater intact with volume of bamboo. It wasfacilitated by polar part of water to generate the heat and encourage the more removal of amorphous parts (lignin and hemicellulose). The extractive as non structural component was also affected by this heating, in which the more severe pretreatment tended to remove a higher extractive in ethanol-benzene. Even though, the main thermal effect focused to increase the accesible area of substrate, however extractive has also potency to inhibit the hydrolytic enzymatic. Removal of this component was suggested help to provide more ready substrate to be hydrolyzed. The high cellulose loss was not expected due to reducing the possibility of the carbohydrate source to convert into fermentable sugar. Considering the weight loss, alpha cellulose and hemicellulose loss after pretreatment, thus microwave pretreatment for 5, 10 and $12.5 \mathrm{~min}(330 \mathrm{~W})$ and $5 \mathrm{~min}(770 \mathrm{~W})$ was suggested provide better performance in hydrolysis process.

TABLE I

The Chemical Component Changes Of Pretreated Bamboo

\begin{tabular}{|c|c|c|c|c|c|c|c|}
\hline \multicolumn{2}{|c|}{ Microwave Pretreatment } & \multirow[b]{2}{*}{$\begin{array}{l}\text { Weight } \\
\text { Loss [\%] }\end{array}$} & \multicolumn{4}{|c|}{ Component $[\mathrm{Wt} \%]$} & \multirow[b]{2}{*}{ Ash } \\
\hline $\begin{array}{c}\text { Power } \\
\text { Loading }[\mathrm{W}]\end{array}$ & $\begin{array}{c}\text { Irradiation Time } \\
\text { [Min] }\end{array}$ & & $\begin{array}{c}\text { Et-Ben } \\
\text { Extractive }\end{array}$ & Alpha Cellulose & $\begin{array}{c}\text { Hemi } \\
\text { Cellulose }\end{array}$ & Lignin & \\
\hline 0 & 0 & - & $3.93 \pm 1.01$ & $44.77 \pm 3.30$ & $18.71 \pm 3.39$ & $28.01 \pm 0.61$ & $1.74 \pm 0.06$ \\
\hline \multirow{4}{*}{330} & 5 & $3.06 \pm 0.13$ & $2.22 \pm 0.00$ & $45.84 \pm 2.78$ & $20.26 \pm 0.69$ & $34.34 \pm 0.55$ & $0.92 \pm 0.003$ \\
\hline & 7.5 & $7.49 \pm 4.15$ & $1.85 \pm 0.05$ & $40.72 \pm 1.82$ & $21.31 \pm 0.68$ & $27.02 \pm 2.49$ & $0.10 \pm 0.007$ \\
\hline & 10 & $2.89 \pm 1.44$ & $2.26 \pm 0.02$ & $45.57 \pm 0.45$ & $21.73 \pm 1.03$ & $31.35 \pm 0.22$ & $0.66 \pm 0.007$ \\
\hline & 12.5 & $4.84 \pm 1.49$ & $2.25 \pm 0.02$ & $47.89 \pm 0.25$ & $19.87 \pm 1.21$ & $30.07 \pm 0.25$ & $0.75 \pm 0.006$ \\
\hline \multirow{4}{*}{550} & 5 & $5.52 \pm 1.34$ & $2.48 \pm 0.02$ & $38.12 \pm 1.02$ & $26.95 \pm 1.45$ & $28.23 \pm 0.61$ & $0.59 \pm 0.004$ \\
\hline & 7.5 & $4.53 \pm 0.98$ & $2.49 \pm 0,03$ & $42.03 \pm 1.85$ & $25.61 \pm 1.37$ & $23.47 \pm 2.61$ & $1.13 \pm 0.012$ \\
\hline & 10 & $4.99 \pm 1.85$ & $2.45 \pm 0.05$ & $38.78 \pm 2.96$ & $28.45 \pm 3.87$ & $24.91 \pm 1.32$ & $0.83 \pm 0.020$ \\
\hline & 12.5 & $5.17 \pm 1.10$ & $2.40 \pm 0.02$ & $40.74 \pm 0.74$ & $25.65 \pm 1.99$ & $25.19 \pm 0.17$ & $1.44 \pm 0.010$ \\
\hline \multirow{4}{*}{770} & 5 & $1.90 \pm 0.61$ & $2.59 \pm 0.01$ & $41.52 \pm 1.58$ & $22.30 \pm 1.79$ & $22.58 \pm 3.89$ & $0.55 \pm 0.221$ \\
\hline & 7.5 & $6.87 \pm 0.76$ & $3.32 \pm 0.02$ & $35.81 \pm 4.31$ & $25.42 \pm 1.90$ & $27.78 \pm 0.21$ & $0.41 \pm 0.057$ \\
\hline & 10 & $6.39 \pm 2.11$ & $3.13 \pm 0.06$ & $42.96 \pm 2.23$ & $17.76 \pm 2.56$ & $22.91 \pm 1.47$ & $0.92 \pm 0.018$ \\
\hline & 12.5 & $14.72 \pm 6.39$ & $5.39 \pm 0.17$ & $40.55 \pm 0.98$ & $12.61 \pm 2.54$ & $22.90 \pm 1.47$ & $0.85 \pm 0.027$ \\
\hline
\end{tabular}

\section{B. Carbohydrate Changes after Microwave Irradiation of Bamboo}

FTIR spectroscopy was used to brief understand the cellulosic structure changes under microwave heating (Fig 1).All intensity bands of pretreated samples decreased at 330 and $550 \mathrm{~W}$ power loading. However this treatment did not cause the changes in functional groups. A strong broad absorption at 3441-3286 $\mathrm{cm}^{-1}$ was observed to $\mathrm{H}$-bonded $\mathrm{OH}$ groups from cellulose I. The major structural changes were absorption broadening of band in this region associating the weaknesses of O-H group [31]. It related with direct delivery of microwave energy to polysaccharides via molecular interactions with electromagnetic field [32]. 

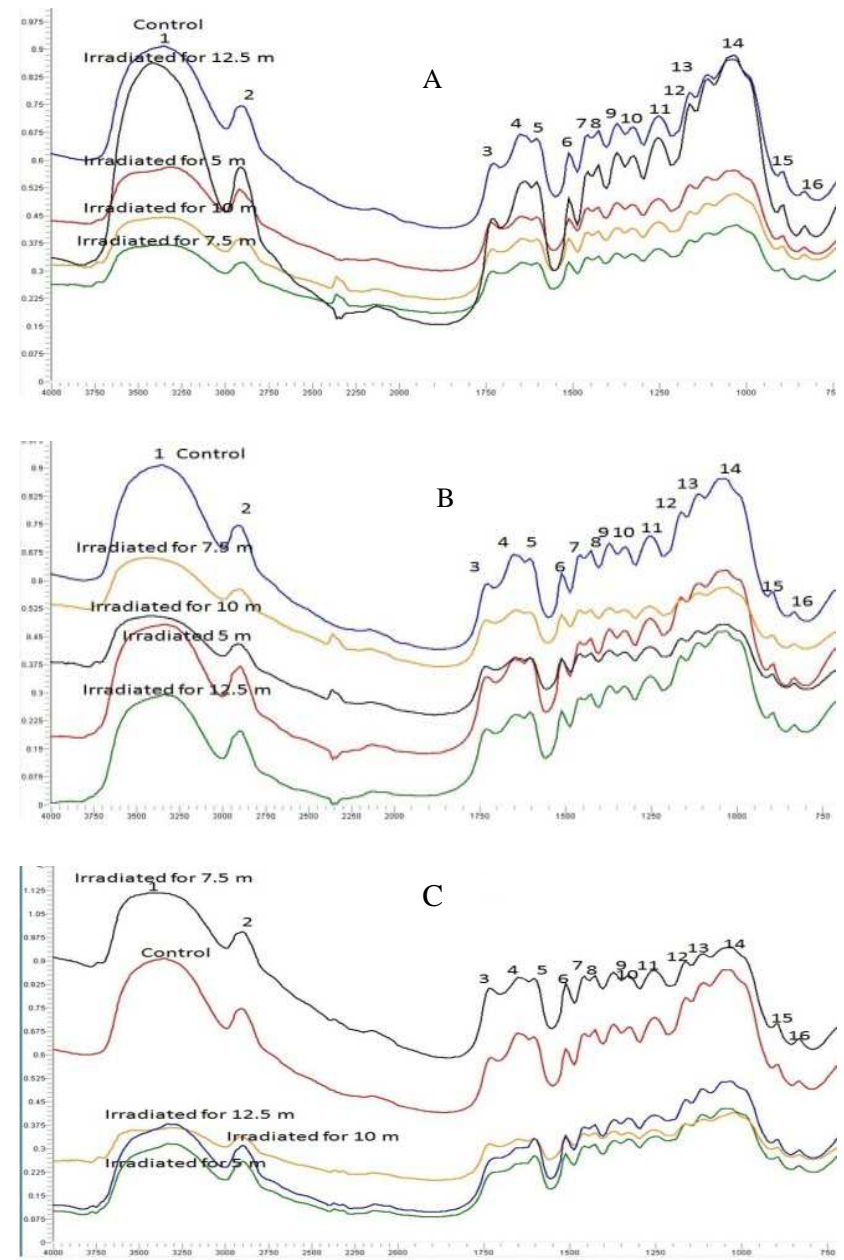

Fig. 1 FTIR spectra of pretreated bamboo under microwave irradiation at (A) $330 \mathrm{~W}$ (B) $550 \mathrm{~W}$ and (C) $770 \mathrm{~W}$

Moreover, the polar molecule vibration and ion movement generate heat and extensive collisions accelerating chemical, biological and physical processes [33]. The microwave irradiation enhanced saponification of intermolecular ester bonds cross-linking xylan and other components such as lignin and other hemicelluloses. The intensity of $\mathrm{O}-\mathrm{H}$ band tends to decrease caused by its consumption in this reaction [34]. The other prominent at $2908-2900 \mathrm{~cm}^{-1}$ is related with C-H stretching in methyl and methylene groups [29, 35-36]. The all assignments of IR band to various components during microwave pre-treatment on bamboo according to literature were summarized in Table 2 .

The well-defined peaks in the finger print can be founded in the region between 1800 and $600 \mathrm{~cm}^{-1}$ appear. Bands at $1000-1200 \mathrm{~cm}^{-1}$ were related to structural features of carbohydrate. The increasing of absorption peaks at 1000$1100 \mathrm{~cm}^{-1}$ after microwaving indicated the enhancement of cellulose content [37]. Lignin structure can be identified in the region of 1600 and $1510 \mathrm{~cm}^{-1}$ (aromatic ring vibration),
1470 and $1460 \mathrm{~cm}^{-1}(\mathrm{C}-\mathrm{H}$ deformations and aromatic ring vibrations) [38]. Guaiacyl (G) and syringyl (S) propane units of lignin polymer can be observed at $1327 \mathrm{~cm}^{-1}$ for syringyl and $1257 \mathrm{~cm}^{-1}$ for guaicyl. There was a slight shifting of wave number in all treatments. The lowest lignin content was founded after irradiation for 5 and $7.5 \mathrm{~min}$ at $770 \mathrm{~W}$, respectively. It was confirmed by aborbancies of FTIR spectra at $1327 \mathrm{~cm}^{-1}$ and $1257 \mathrm{~cm}^{-1}$. Absorbance in all treatments of $1327 \mathrm{~cm}^{-1}$ (syringyl) was lower than that of guiacyl $\left(1257 \mathrm{~cm}^{-1}\right)$ showed that syringil propane unit was lower than that of guaicyl lignin under microwave pretreatment. The band around $1605 \mathrm{~cm}^{-1}$ (C-Ph vibration) as lignin moties disappeared at microwave pretreatment for 5 $\min (550 \mathrm{~W})$. While, the intesity decrease on the band around of $895 \mathrm{~cm}^{-1}$ assigned to $\beta$-glicosidic linkage in cellulose [39] exhibited in all spectras indicating the cellulose loss after microwave heating. The band at 1736$1728 \mathrm{~cm}^{-1}$ associated with unconjugated $\mathrm{C}=0$ in xylan in hemicellulose disapearred in FTIR spectra at microwave pretreatment for $12.5 \mathrm{~min}(770 \mathrm{~W})$.

\section{Morphological Characteristics of Microwave Pretreated Bamboo}

Scanning electron microscope (SEM) images of raw bamboo and selected pretreated bamboo were demonstrated in Fig.2. Microwaved samples for 5, 10, $12.5 \mathrm{~min}$ (330 W) and $5 \mathrm{~min}$ at $770 \mathrm{~W}$ were choosen to observe due to the lower in weight loss relative than the other treatments considering the hemicellulose and alfa cellulose changes during pretreatment. The complete, compact structure of raw bamboo is clearly observed, while microwave heating destroyed on the structure of pretreated bamboo such as holes, crack on the surface and soften structure. The energy source of microwave and substrate lead polar molecular vibration and create hot spotcaused disruption on carbohydrate and lignin network, partial lignin cleavage, and hemicellulose removal on pretreated bamboo. Furthermore, the beneficial aspect of microwave irradiation could enhance the lignin degradation and provide the potential of exposing cellulose and increasing cellulose contents [22]. This finding was in line with the morphological observation after microwave pre-treatment on bagasse [10].

Disorganization of pretreated bamboo morphology was assumed lead a greater fiber exposure to enhance the possibility of digestibility improvement. Lignin and hemicelluloses removal lead to break the some ether bonds in lignin and lignin-carbohydrate complex and weaken the hydrogen bonds in cellulose and promoted fibrillation [30]. Moreover, the fragmentation enlarged the specific surface area of biomass [10]. However, the extent level of microwave irradiation at $330 \mathrm{~W}$ has only slight difference effect on fiber degradation. 
TABLE II

ASSIGMENTS OF IR BAND OF Microwave PrETREATMENT ON BAMBOo ACCORDING To Literature

\begin{tabular}{|c|c|c|c|c|c|c|c|c|c|c|c|c|c|c|}
\hline \multirow{3}{*}{ No } & \multirow{2}{*}{ Control } & \multicolumn{4}{|c|}{$330 \mathrm{~W}$ of power loading } & \multicolumn{4}{|c|}{$550 \mathrm{~W}$ of power loading } & \multicolumn{4}{|c|}{$770 \mathrm{~W}$ of power loading } & \multirow{2}{*}{ Functional groups } \\
\hline & & $5 \mathrm{~m}$ & $\begin{array}{l}7.5 \\
\mathrm{~m}\end{array}$ & $\begin{array}{l}10 \\
\mathrm{~m}\end{array}$ & $\begin{array}{c}12.5 \\
\mathrm{~m}\end{array}$ & $5 \mathrm{~m}$ & $\begin{array}{c}7.5 \\
\mathrm{~m}\end{array}$ & $\begin{array}{l}10 \\
\mathrm{~m}\end{array}$ & $\begin{array}{c}12.5 \\
\mathrm{~m}\end{array}$ & $5 \mathrm{~m}$ & $\begin{array}{l}7.5 \\
\mathrm{~m}\end{array}$ & $\begin{array}{l}10 \\
\mathrm{~m}\end{array}$ & $\begin{array}{c}12.5 \\
\mathrm{~m}\end{array}$ & \\
\hline & \multicolumn{14}{|c|}{ Wave number $(\mathrm{cm}-1)$} \\
\hline 1 & 3394 & 3379 & 3425 & 3333 & 3402 & 3371 & 3441 & 3418 & 3355 & 3371 & 3371 & 3286 & 3348 & $\begin{array}{l}\text { A strong and broad hydrogen bond } \\
(\mathrm{O}-\mathrm{H}) \text { stretching absorption }\end{array}$ \\
\hline 2 & 2901 & 2908 & 2908 & 2901 & 2908 & 2908 & 2901 & 2916 & 2900 & 2900 & 2908 & 2908 & 2901 & $\begin{array}{l}\text { A prominent C-H stretching } \\
\text { absorption }^{1}\end{array}$ \\
\hline 3 & 1736 & 1728 & 1736 & 1736 & 1728 & 1728 & 1736 & 1736 & 1728 & 1728 & 1728 & 1736 & - & Unconjugated $\mathrm{C}=\mathrm{O}$ in xylans ${ }^{1}$ \\
\hline 4 & 1643 & 1674 & 1651 & 1651 & 1643 & 1674 & 1643 & 1643 & 1643 & 1681 & 1682 & 1651 & 1659 & $\begin{array}{l}\text { Absorbed } \mathrm{O}-\mathrm{H} \text { and conjugated C- } \\
\mathrm{O}^{1}\end{array}$ \\
\hline 5 & - & 1589 & 1605 & 1605 & 1596 & & 1605 & 1605 & 1612 & 1612 & 1612 & 1605 & 1605 & $\mathrm{C}-\mathrm{Ph}$ vibration $^{1}$ \\
\hline 6 & 1512 & 1512 & 1512 & 1512 & 1512 & 1512 & 1512 & 1512 & 1512 & 1512 & 1512 & 1512 & 1512 & Aromatic skeletal $^{1}$ \\
\hline 7 & 1458 & 1473 & 1458 & 1458 & 1458 & 1458 & 1458 & 1458 & 1458 & 1458 & 1458 & 1458 & 1459 & $\mathrm{C}-\mathrm{H}$ deformation ${ }^{1}$ \\
\hline 8 & 1427 & 1411 & 1427 & 1427 & 1434 & 1442 & 1427 & 1427 & 1442 & 1442 & 1443 & 1427 & 1412 & C- $\mathrm{H}_{2}$ scissoring motion ${ }^{1}$ \\
\hline 9 & 1373 & 1365 & 1373 & 1373 & 1373 & 1365 & 1373 & 1373 & 1373 & 1365 & 1366 & 1373 & 1358 & $\mathrm{C}-\mathrm{H}$ deformation ${ }^{1}$ \\
\hline \multirow[b]{2}{*}{10} & \multirow[b]{2}{*}{1335} & \multirow[b]{2}{*}{1303} & \multirow[b]{2}{*}{1327} & \multirow[b]{2}{*}{1335} & \multirow[b]{2}{*}{1334} & \multirow[b]{2}{*}{1334} & \multirow[b]{2}{*}{1327} & \multirow[b]{2}{*}{1327} & \multirow[b]{2}{*}{1334} & \multirow[b]{2}{*}{1334} & \multirow[b]{2}{*}{1335} & \multirow[b]{2}{*}{1335} & \multirow[b]{2}{*}{1335} & C-H vibration ${ }^{1}$ \\
\hline & & & & & & & & & & & & & & $\begin{array}{l}\text { C1-O vibration in syringyl } \\
\text { derivates }{ }^{1}\end{array}$ \\
\hline \multirow[t]{2}{*}{11} & \multirow[t]{2}{*}{1257} & \multirow[t]{2}{*}{1257} & \multirow{2}{*}{1257} & \multirow{2}{*}{1257} & \multirow{2}{*}{1257} & \multirow{2}{*}{1249} & \multirow{2}{*}{1257} & \multirow{2}{*}{1257} & \multirow{2}{*}{1243} & 1249 & 1250 & 1257 & 1250 & Guaiacyl ring $^{1}$ \\
\hline & & & & & & & & & & & & & & $\mathrm{C}-\mathrm{O}$ stretch $^{1}$ \\
\hline 12 & 1165 & 1141 & 1165 & 1165 & 1165 & 1195 & 1165 & 1165 & 1164 & 1203 & 1203 & 1165 & 1157 & C-O-C vibration ${ }^{1}$ \\
\hline 13 & 1111 & 1103 & 1111 & 1111 & 1141 & 1087 & 1111 & 1111 & 1087 & 1087 & 1088 & 1111 & 1103 & Aromatic skeletal and C-O stretch ${ }^{1}$ \\
\hline 14 & 1049 & 1049 & 1041 & 1034 & 1041 & 1033 & 1034 & 1034 & 1033 & 1041 & 1041 & 1026 & 1034 & $\mathrm{C}-\mathrm{O}$ stretch $^{1}$ \\
\hline 15 & 895 & 879 & 895 & 895 & 864 & 864 & 895 & 895 & 864 & 872 & 872 & 895 & 879 & $\begin{array}{l}\mathrm{C}-\mathrm{O}-\mathrm{C} \text { stretching at } \beta \text {-glicosidic } \\
\text { linkage or } \mathrm{C}-\mathrm{H} \text { deformation in } \\
\text { Cellulose }^{2}\end{array}$ \\
\hline 16 & 833 & 840 & 833 & 833 & 833 & 833 & 833 & 833 & 833 & 841 & 841 & 833 & 841 & $\mathrm{C}-\mathrm{H}$ vibration ${ }^{3}$ \\
\hline
\end{tabular}

${ }^{1}$ Pandey and Pitman [25], ${ }^{2}$ Nelson and O'Connor [39], ${ }^{3}$ Cheng et al. [10]

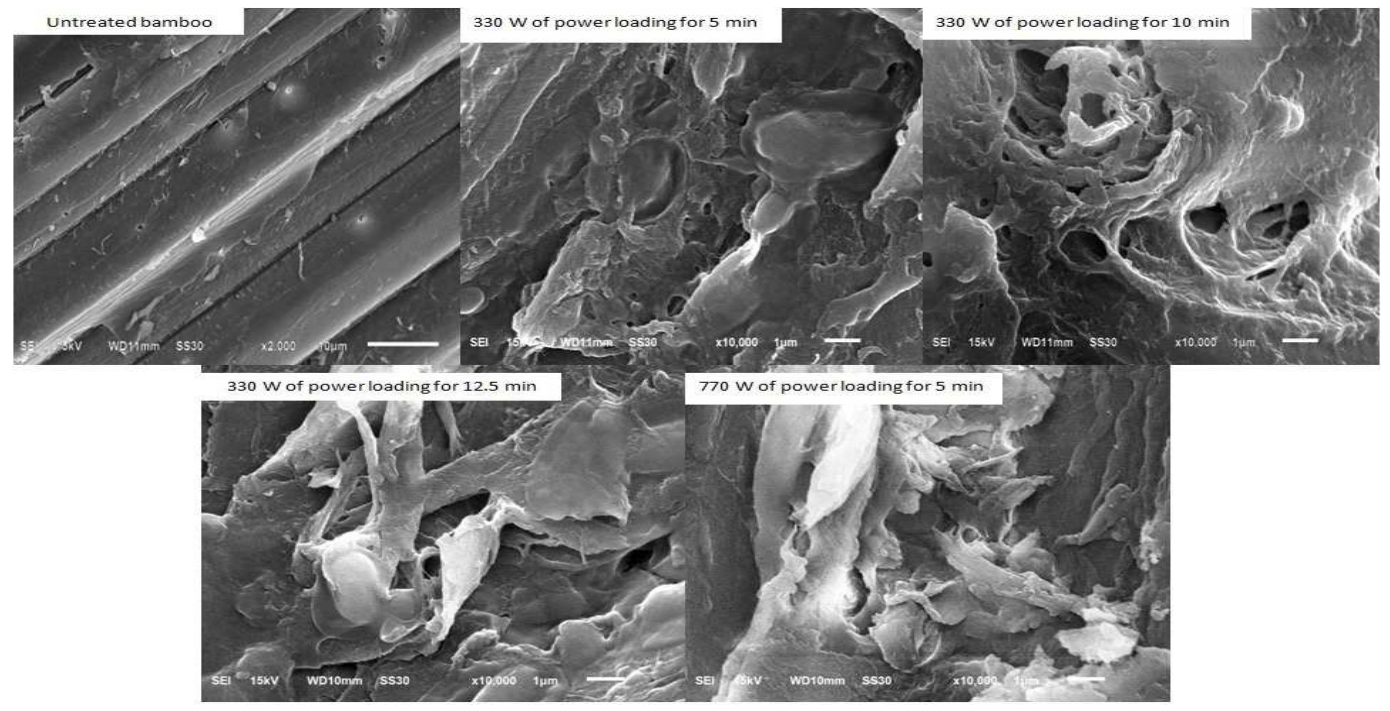

Fig.2 SEM images of selected microwaved bamboo under various power loading and irradiation time 
TABLE III

Element Weight Percentage Changes Of Microwave-Pretreated BАMBOO

\begin{tabular}{|c|c|c|c|c|c|}
\hline \multirow{3}{*}{ Element } & \multirow{2}{*}{ Control } & \multicolumn{4}{|c|}{ Microwave Pretreatment } \\
\hline & & $\begin{array}{c}5 \mathrm{~min} \\
(330 \mathrm{~W})\end{array}$ & $\begin{array}{l}10 \mathrm{~min} \\
(330 \mathrm{~W})\end{array}$ & $\begin{array}{c}12.5 \mathrm{~min} \\
(330 \mathrm{~W})\end{array}$ & $\begin{array}{c}5 \mathrm{~min} \\
(770 \mathrm{~W})\end{array}$ \\
\hline & $\mathrm{wt} \%$ & wt $\%$ & wt $\%$ & $\mathrm{wt} \%$ & $\mathrm{wt} \%$ \\
\hline $\mathrm{C}$ & $49.54 \pm 0.13$ & $\begin{array}{c}48.64 \pm \\
0.15 \\
\end{array}$ & $\begin{array}{c}50.12 \pm \\
0.13 \\
\end{array}$ & $\begin{array}{c}50.84 \pm \\
0.11 \\
\end{array}$ & $\begin{array}{c}51.24 \pm \\
0.10 \\
\end{array}$ \\
\hline $\mathrm{O}$ & $38.90 \pm 0.61$ & $\begin{array}{c}32.88 \pm \\
0.62 \\
\end{array}$ & $\begin{array}{c}40.13 \pm \\
0.56 \\
\end{array}$ & $\begin{array}{c}47.73 \pm \\
0.55 \\
\end{array}$ & $\begin{array}{c}46.97 \pm \\
0.54 \\
\end{array}$ \\
\hline $\mathrm{F}$ & $0.33 \pm 0.94$ & $\begin{array}{c}0.15 \pm \\
0.88\end{array}$ & - & - & 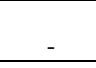 \\
\hline $\mathrm{Si}$ & $0.01 \pm 0.39$ & $\begin{array}{c}0.54 \pm \\
0.40 \\
\end{array}$ & $\begin{array}{c}1.59 \pm \\
0.35 \\
\end{array}$ & $\begin{array}{c}0.29 \pm \\
0.35 \\
\end{array}$ & $\begin{array}{c}0.31 \pm \\
0.34 \\
\end{array}$ \\
\hline $\mathrm{Cu}$ & $5.63 \pm 6.04$ & $\begin{array}{c}9.17 \pm \\
5.98 \\
\end{array}$ & $\begin{array}{c}4.17 \pm \\
5.54 \\
\end{array}$ & $\begin{array}{c}0.24 \pm \\
5.78 \\
\end{array}$ & - \\
\hline $\mathrm{Pb}$ & $5.60 \pm 1.64$ & $\begin{array}{c}8.62 \pm \\
1.66 \\
\end{array}$ & $\begin{array}{c}3.99 \pm \\
1.50 \\
\end{array}$ & $\begin{array}{c}0.90 \pm \\
1.52 \\
\end{array}$ & $\begin{array}{c}1.48 \pm \\
1.46 \\
\end{array}$ \\
\hline Total & 100 & 100 & 100 & 100 & 100 \\
\hline
\end{tabular}

The changes of element constituent in weight after microwave heating based on EDX analysis was demonstrated in Table 3. The major element of the raw and pretreated bamboo was Carbon $(\mathrm{C})$ and Oxygen $(\mathrm{O})$ due to these components is structural component of cell wall bamboo. The minor element constituent of lignocellulosic materials included as inorganic constituent in ash content such as $\mathrm{F}$ (Fluorine), $\mathrm{Pb}$ (Plumbum), $\mathrm{Si}$ (Silicon) and $\mathrm{Cu}$ (Cupprum) appeared in raw bamboo. However, pretreatment for 10 and $12.5 \mathrm{~min}(330 \mathrm{~W})$ and $5 \mathrm{~min}$ at $770 \mathrm{~W}$ causedFluorine loss, while Cupprum disappeared on the bamboo pretreated for $5 \mathrm{~min}(330 \mathrm{~W})$. Except microwaving for $5 \mathrm{~min}(330 \mathrm{~W})$, the thermal treatment caused carbon and oxygen increasing compared to control. Even though, the bark-less bamboo was used in this research, however $\mathrm{Si}$ as major element in bark was still found.

\section{Crystalline Allomorph and Crystallite Size of Pretreated Bamboo}

The entire document should be in Times New Roman or Times font. Type 3 fonts must not be used. Other font types may be used if needed for special purposes. Recommended font sizes are shown in Table 1.

Table 4 showed the crystalline allomorph of pretreated bamboo observed by XRD analysis. It well known that the cellulose I composed of $\mathrm{I}_{\alpha}$ (one-chain triclinic) and $\mathrm{I}_{\beta}$ (twochain monoclinic cells) allomorph type [40] which can be determined by $\mathrm{Z}$-discriminant $\mathrm{Z}<0$ and $\mathrm{Z}>0$, respectively. Cellulose triclinic $\left(\mathrm{I}_{\alpha}\right)$ is meta stable and more reactive than monoclinic $\left(\mathrm{I}_{\beta}\right)$ and heat annealing of all celluloses tend to produce $I_{\beta}$ ([40],[41]). $I_{\alpha}$ phase was suggested more degradable than that of $I_{\beta}$, thus it was expected an improving cellulose digestibility occurred [42]. Crystal allomorph of control in monoclinic form after microwave pretreatment in several conditions this allomorph changed to triclinic. After bamboo was irradiated for $12.5 \mathrm{~min}$ at $330 \mathrm{~W}$, monoclinic structure of cellulose transformed to triclinic structure. The increasing of power loading, the cellulose allomorph transformation tends to increase and the most severe pretreatment condition the cellulose $I_{\beta}$ was to be final product. It was supported by previous study [41] related with heat treatment and irradiation time tendency [43],[44].

Crystallite size of cellulose in bamboo varied at lattice planes (101), (10-1) and (002). The highest crystallite size of cellulose at (002) lattice plane $(6.19 \mathrm{~nm})$ was determined after microwaving for $12.5 \mathrm{~min}(550$ and $770 \mathrm{~W})$ and $10 \mathrm{~min}$ $(550 \mathrm{~W})$. Compared to crystallite size after biological pretreatment of bamboo this value was higher [45]. In addition, the crystallite size of hemp bast fiber, wheat straw and cotton linter has been reported in previous studies [46],[47] was lower that that of these data.The length of crystallite area was described by crystallite size at (040) lattice plane. In general, the increasing of power loading and irradiation time had no similar effect on length of crystallite area.

TABLE IV

Crystalline Allomorph Of Pretreated Bamboo

\begin{tabular}{|c|c|c|c|c|c|c|c|c|c|}
\hline \multicolumn{2}{|c|}{$\begin{array}{c}\text { Microwave } \\
\text { Pretreatment }\end{array}$} & \multicolumn{4}{|c|}{ Crystallite size $[\mathrm{nm}]$} & \multicolumn{3}{|c|}{ Crystallite allomorph } & \multirow[b]{2}{*}{ Crystal allomorph } \\
\hline $\begin{array}{c}\text { Power } \\
\text { loading } \\
\text { [Watt] }\end{array}$ & $\begin{array}{c}\text { Irradiation } \\
\text { time } \\
\text { [Minutes] }\end{array}$ & $\begin{array}{c}\mathrm{D} \\
(101)\end{array}$ & $\begin{array}{c}\mathrm{D} \\
(10-1)\end{array}$ & $\begin{array}{c}\mathrm{D} \\
(002)\end{array}$ & $\begin{array}{c}\mathrm{D} \\
(040)\end{array}$ & $\begin{array}{c}\mathrm{d} \\
(101)\end{array}$ & $\begin{array}{c}\mathrm{d} \\
(10-1)\end{array}$ & $\mathrm{z}$ & \\
\hline 0 & 0 & 5.46 & 8.71 & 5.59 & 16.52 & 0.5824 & 0.5349 & -45.47 & $\mathrm{I}_{\beta}$ \\
\hline \multirow{4}{*}{330} & 5 & 10.10 & - & 5.85 & 14.93 & 0.6019 & 0.5507 & -26.66 & $\mathrm{I}_{\beta}$ \\
\hline & 7.5 & 5.84 & 7.97 & 5.70 & 21.53 & 0.5877 & 0.5342 & -35.97 & $\mathrm{I}_{\beta}$ \\
\hline & 10 & 13.35 & - & 5.77 & 20.44 & 0.6118 & 0.5413 & -1.47 & $\mathrm{I}_{\beta}$ \\
\hline & 12,5 & 4.80 & 4.80 & 5.68 & 40.89 & 0.6345 & 0.5562 & 23.47 & $\mathrm{I} \alpha$ \\
\hline \multirow{4}{*}{550} & 5 & 17.79 & 6.46 & 5.32 & 20.44 & 0.6195 & 0.5400 & 12.655 & $\mathrm{I} \alpha$ \\
\hline & 7.5 & 5.35 & - & 5.74 & 25.06 & 0.5576 & 0.5342 & -86.92 & $\mathrm{I}_{\beta}$ \\
\hline & 10 & 9.83 & - & 6.19 & 16.88 & 0.6135 & 0.5323 & 9.53 & $\mathrm{I} \alpha$ \\
\hline & 12.5 & 13.35 & - & 6.19 & 12.15 & 0.6102 & 0.5407 & -3.71 & $\mathrm{I}_{\beta}$ \\
\hline \multirow{4}{*}{770} & 5 & 9.01 & 5.86 & 5.92 & 26.76 & 0.6077 & 0.5224 & 8.59 & $\mathrm{I} \alpha$ \\
\hline & 7,5 & 16,24 & - & 5.70 & 30.34 & 0.6291 & 0.5439 & 25.37 & $\mathrm{I} \alpha$ \\
\hline & 10 & 19.66 & 4.83 & 5.74 & 26.76 & 0.6399 & 0.5558 & 33.03 & $\mathrm{I} \alpha$ \\
\hline & 12.5 & 5.94 & 8.72 & 6.19 & 26.78 & 0.5653 & 0.5199 & -60.88 & $I_{\beta}$ \\
\hline
\end{tabular}




\section{E. Biodegradation Pattern}

Biodegradation patterns of bamboo during microwave pretreatment under various power loading and irradiation time were examined by FTIR analysis (Table 4 and Fig.3).The relative changes in the intensities of lignin peaks at $1512 \mathrm{~cm}^{-1}$ (aromatic skeletal) in lignin against four carbohydrate peaks at $1736(\mathrm{C}=\mathrm{O}$ in xylan), $1373(\mathrm{C}-\mathrm{H}$ deformation in cellulose and hemicelluloses), 1165 (C-O-C vibration in cellulose and hemicelluloses), $897 \mathrm{~cm}^{-1}$ (C-H deformation or $\mathrm{C}-\mathrm{O}-\mathrm{C}$ stretching at the $\beta$-glycosidic linkage characteristics in cellulose) calculated by peak heights and areas [25].

There was an increase in lignin/carbohydrate ratio until irradiation time for $7.5 \mathrm{~min}$ at $330 \mathrm{~W}$, then a long with the increasing of irradiation time this ratio tended to decrease. It indicated this pretreatment had selective lignin-degrading ability. The selectivity turned into non selective degradation until microwave irradiation for $10 \mathrm{~min}(550 \mathrm{~W})$. The increase of the other ratios indicated that hemicellulose and cellulose degradation levels were higher. Generally, there were no pattern changes in this ratio along with increasing irradiation time in $770 \mathrm{~W}$ of power loading. The lost of functional group at $1736 \mathrm{~cm}^{-1}$ in the power loading $770 \mathrm{~W}$ for $12.5 \mathrm{~min}$ caused this lignin/carbohydrate ratio can be calculated.

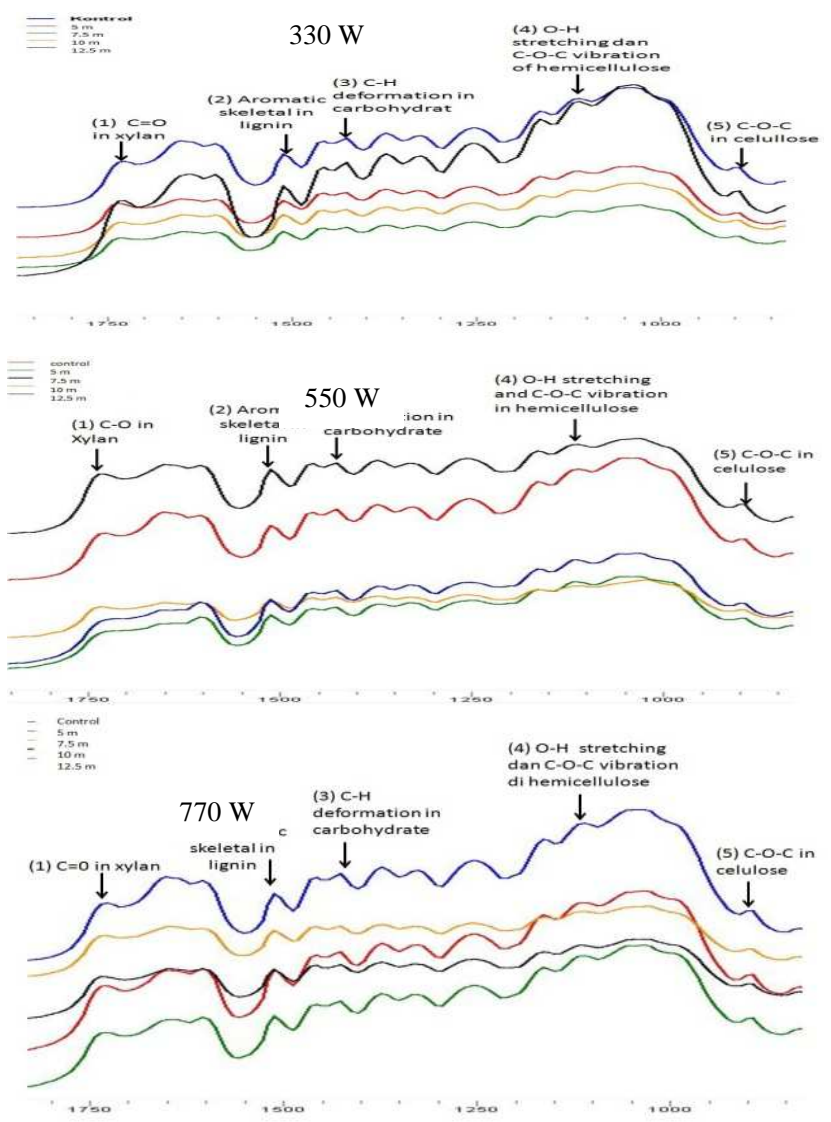

Fig. 3. FTIR spectra of microwave pretreated bamboo at (1) $1736 \mathrm{~cm}^{-1}$, (2) $1512 \mathrm{~cm}^{-1}$, (3) $1373 \mathrm{~cm}^{-1}$, (4) $1165 \mathrm{~cm}^{-1}$, (5) $897 \mathrm{~cm}^{-1}$

\section{F. Crystallinity index (CI) and Lateral Order Index (LOI) of Cellulose}

The crystallinity index and LOI of cellulose during microwave pretreatment was listed in Table 5. The changes of cellulose after pretreatment can be interpreted by CI, naturally, cellulose chains contain both crystalline (ordered) and amorphous (less ordered) regions. CI describes the relative amount of crystalline portion in cellulose compared to amorphous region. This index is a major factor that affected enzymatic hydrolysis [48],[49].

TABLE V

Biodegradation Patterns OF BAMboo Under MicrowaVe PRETREATMENT

\begin{tabular}{|c|c|c|c|c|c|}
\hline \multirow{2}{*}{$\begin{array}{c}\text { Power } \\
{[\mathrm{W}]}\end{array}$} & \multirow{2}{*}{$\begin{array}{c}\text { Irradiati } \\
\text { on } \\
\text { [min] }\end{array}$} & \multicolumn{4}{|c|}{$\begin{array}{l}\text { Relative intensities of aromatic skeletal vibration } \\
\left(I_{1512}\right) \text { against typical bands for carbohydrates }\end{array}$} \\
\hline & & $I_{1512} / I_{1736}$ & $I_{1512} / I_{1373}$ & $I_{1512} / I_{1165}$ & $I_{1512} / I_{897}$ \\
\hline 0 & 0 & $\begin{array}{c}1.04 \\
(1.06)\end{array}$ & $\begin{array}{c}1.02 \\
(1.06)\end{array}$ & $\begin{array}{c}0.98 \\
(0.95)\end{array}$ & $\begin{array}{c}1.28 \\
(1.29)\end{array}$ \\
\hline \multirow{4}{*}{330} & 5 & $\begin{array}{c}1.02 \\
(0.89)\end{array}$ & $\begin{array}{c}0.92 \\
(0.57)\end{array}$ & $\begin{array}{c}0.85 \\
(0.39)\end{array}$ & $\begin{array}{l}1.19 \\
(0.59)\end{array}$ \\
\hline & 7.5 & $\begin{array}{r}1.00 \\
(0.60)\end{array}$ & $\begin{array}{c}0.98 \\
(0.60)\end{array}$ & $\begin{array}{c}0.94 \\
(0.43)\end{array}$ & $\begin{array}{c}1.24 \\
(3.00) \\
\end{array}$ \\
\hline & 10 & $\begin{array}{c}1.07 \\
(0.60)\end{array}$ & $\begin{array}{c}0.91 \\
(0.60)\end{array}$ & $\begin{array}{c}0.84 \\
(0.38)\end{array}$ & $\begin{array}{c}1.03 \\
(3.00)\end{array}$ \\
\hline & 12.5 & $\begin{array}{c}1.14 \\
(1.28)\end{array}$ & $\begin{array}{c}0.81 \\
(0.88) \\
\end{array}$ & $\begin{array}{c}0.67 \\
(0.48)\end{array}$ & $\begin{array}{c}1.25 \\
(0.98)\end{array}$ \\
\hline \multirow{4}{*}{550} & 5 & $\begin{array}{l}1.15 \\
(0.91)\end{array}$ & $\begin{array}{c}0.85 \\
(0.71) \\
\end{array}$ & $\begin{array}{c}0.83 \\
(0.40)\end{array}$ & $\begin{array}{c}1.22 \\
(0.86)\end{array}$ \\
\hline & 7.5 & $\begin{array}{l}1.04 \\
(0.50)\end{array}$ & $\begin{array}{c}0.96 \\
(0.50)\end{array}$ & $\begin{array}{c}0.93 \\
(0.38)\end{array}$ & $\begin{array}{c}1.13 \\
(3.00)\end{array}$ \\
\hline & 10 & $\begin{array}{l}1.05 \\
(0.50)\end{array}$ & $\begin{array}{c}0.95 \\
(0.50)\end{array}$ & $\begin{array}{c}0.87 \\
(0.38)\end{array}$ & $\begin{array}{c}1.11 \\
(3.00)\end{array}$ \\
\hline & 12.5 & $\begin{array}{c}1.25 \\
(0.90)\end{array}$ & $\begin{array}{c}0.78 \\
(0.71)\end{array}$ & $\begin{array}{c}0.63 \\
(0.40)\end{array}$ & $\begin{array}{c}1.25 \\
(0.72)\end{array}$ \\
\hline \multirow{4}{*}{770} & 5 & $\begin{array}{c}1.08 \\
(1.13)\end{array}$ & $\begin{array}{c}0.86 \\
(0.87)\end{array}$ & $\begin{array}{c}0.67 \\
(0.18)\end{array}$ & $\begin{array}{c}1.23 \\
(0.82)\end{array}$ \\
\hline & 7.5 & $\begin{array}{c}1.02 \\
(0.50)\end{array}$ & $\begin{array}{c}0.96 \\
(0.50)\end{array}$ & $\begin{array}{c}0.92 \\
(0.40)\end{array}$ & $\begin{array}{c}1.19 \\
(1.50)\end{array}$ \\
\hline & 10 & $\begin{array}{c}1.06 \\
(1.00)\end{array}$ & $\begin{array}{c}0.94 \\
(1.00)\end{array}$ & $\begin{array}{c}0.89 \\
(0.78)\end{array}$ & $\begin{array}{c}1.13 \\
(3.50)\end{array}$ \\
\hline & 12.5 & $-(-)$ & $\begin{array}{c}0.88 \\
(0.79)\end{array}$ & $\begin{array}{c}0.70 \\
(0.44)\end{array}$ & $\begin{array}{c}1.12 \\
(0.63)\end{array}$ \\
\hline
\end{tabular}

To improve conversion of cellulose polymer into the sugar release the cellulose structure mainly in the crystalline region is required to be opened. Microwave heating can help to disrupt the hydrogen bond by increasing splitting effect on crystalline region and maximize amorphous expansion [50]. This treatment caused the increasing of crystallity index compared to control related with removal the amorphous part. The increase of CI suggested that the cellulose became more exposed after pretreatment. The phenomenon was also described in the previous research [22, 51-53]. The fold change of $\mathrm{CI}$ in the pretreated samples compared to control varied from 15.49-30.10\%, inwhich the highest fold change of CI was bamboo irradiated for $10 \mathrm{~min}(330 \mathrm{~W})$.In this condition, the alfacellulose after pretreatment is about $45.57 \%$. The high cellululose content was suggested providing more source to be converted into fermentable sugar. Cellulose structure can be changed by disrupting inter- and intrachain hydrogen bonding of cellulose fibrils during pretreatment [54]. In biomass, hemicellulose and 
lignin are amorphous in nature while cellulose is crystalline [55].

TABLE VI

THE CHANGES OF CRYSTALLINITY INDEX AND LOI UNDER MiCROWAVE HEATING

\begin{tabular}{|c|c|c|c|c|c|c|}
\hline \multicolumn{2}{|c|}{$\begin{array}{c}\text { Microwave } \\
\text { Pretreatment }\end{array}$} & \multicolumn{4}{|c|}{ CI } & \multirow[t]{2}{*}{ LOI } \\
\hline $\begin{array}{c}\text { Power } \\
{[\mathrm{W}]}\end{array}$ & $\begin{array}{c}\text { Irradia } \\
\text { tion } \\
{[\mathrm{min}]}\end{array}$ & $\begin{array}{c}\text { Crysta } \\
\text { line } \\
(\mathrm{Fc})\end{array}$ & $\begin{array}{c}\text { Amorp } \\
\text { hous } \\
(\mathrm{Fa})\end{array}$ & CI & $\begin{array}{c}\text { Fold } \\
\text { change } \\
\text { of CI } \\
(\%)\end{array}$ & \\
\hline 0 & 0 & 0.66 & 1.51 & 30.43 & - & 1.26 \\
\hline \multirow{4}{*}{330} & 5 & 1.05 & 1.83 & 36.39 & 16.36 & 1.22 \\
\hline & 7.5 & 1.47 & 2.01 & 42.13 & 27.77 & 1.27 \\
\hline & 10 & 1.35 & 1.75 & 43.54 & 30.10 & 1.10 \\
\hline & 12.5 & 1.00 & 1.48 & 40.19 & 24.75 & 1.43 \\
\hline \multirow{4}{*}{550} & 5 & 0.80 & 1.42 & 36.01 & 15.49 & 1.26 \\
\hline & 7.5 & 1.16 & 1.83 & 38.89 & 21.75 & 1.16 \\
\hline & 10 & 1.19 & 2.03 & 36.93 & 17.59 & 1.17 \\
\hline & 12.5 & 1.13 & 1.56 & 41.99 & 27.52 & 1.40 \\
\hline \multirow{4}{*}{770} & 5 & 1.24 & 1.85 & 40.17 & 24.23 & 1.33 \\
\hline & 7.5 & 1.32 & 2.08 & 38.79 & 21.55 & 1.21 \\
\hline & 10 & 1.19 & 2.03 & 36.93 & 17.59 & 1.17 \\
\hline & 12.5 & 1.16 & 1.60 & 42.15 & 27.81 & 1.12 \\
\hline
\end{tabular}

To improve conversion of cellulose polymer into the sugar release the cellulose structure mainly in the crystalline region is required to be opened. Microwave heating can help to disrupt the hydrogen bond by increasing splitting effect on crystalline region and maximize amorphous expansion [50]. This treatment caused the increasing of crystallity index compared to control related with removal the amorphous part. The increase of CI suggested that the cellulose became more exposed after pretreatment. The phenomenon was also described in the previous research [22, 51-53]. The fold change of $\mathrm{CI}$ in the pretreated samples compared to control varied from $15.49-30.10 \%$, inwhich the highest fold change of CI was bamboo irradiated for $10 \mathrm{~min}(330 \mathrm{~W})$.In this condition, the alfacellulose after pretreatment is about $45.57 \%$. The high cellululose content was suggested providing more source to be converted into fermentable sugar. Cellulose structure can be changed by disrupting inter- and intrachain hydrogen bonding of cellulose fibrils during pretreatment [54]. In biomass, hemicellulose and lignin are amorphous in nature while cellulose is crystalline [55].

The CI of 5 min irradiation time $(330 \mathrm{~W}$ and $550 \mathrm{~W})$ was lower than the other irradiation time. However, the CI of pretreatment at $770 \mathrm{~W}$ of power loading decreased until irradiation time for $10 \mathrm{~min}$. Besides XRD analysis, FTIR spectroscopy analysis also can be used for observing crystallinity changes through LOI measurement defined as the absorbance ratio of $\mathrm{A}_{1427}$ to $\mathrm{A}_{895}$ [56] of FTIR spectra data. At 330 and $550 \mathrm{~W}$ of power loading, even though there was a decrease in LOI until irradiation for $10 \mathrm{~min}$, in the end of irradiation time the LOI tended to increase.
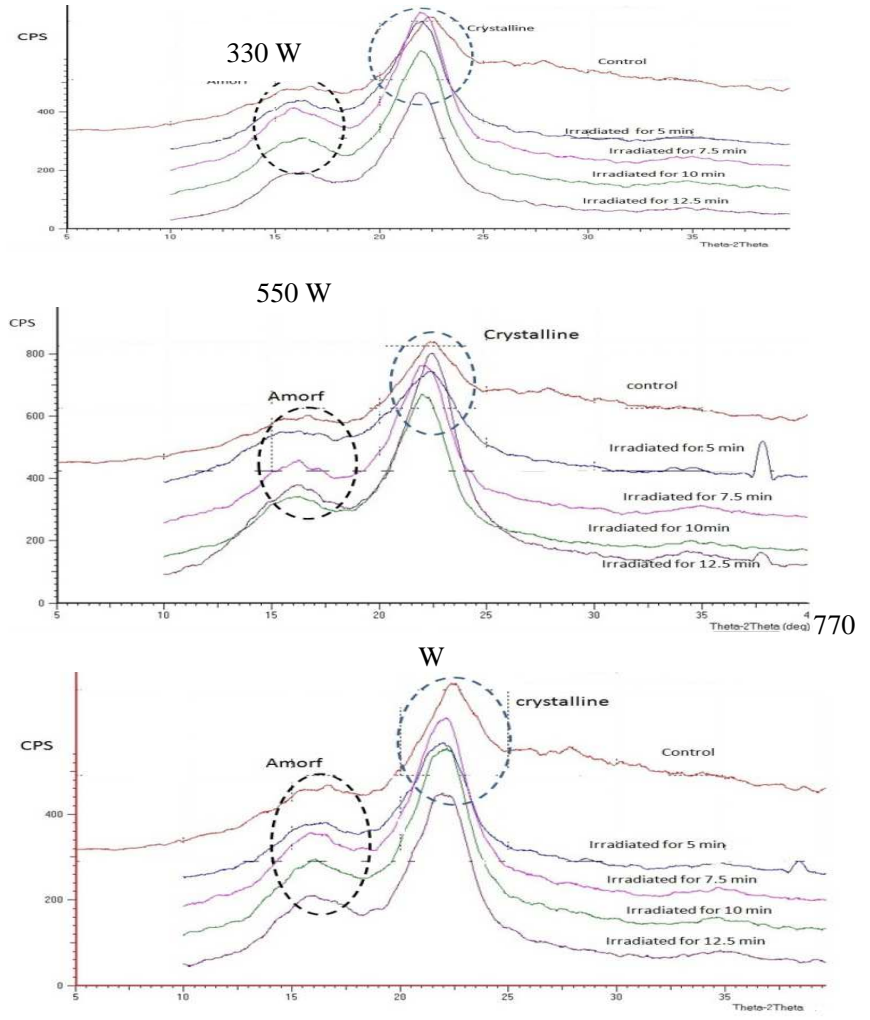

Fig. 4. XRD spectra of bamboo pretreated by microwave pretreatment at various condition

To proceed further into recognition of cellulose structure, the XRD patterns of pretreated materials were sketched in Figure 4. Crystalline and amorphous structure of cellulose can be identified from primary peak of XRD pattern which ranging between $22-23^{0}$ and secondary peak in the range of $16-18^{0}[50,57]$.

These peaks can be determined within the mentioned range for all treatments, which indicates the crystalline and amorphous region of cellulose still appeared. All treatments did not cause changes on cellulose structure I. Intensity transformation in hydrogen bonding of cellulose can be reflected from width variation of crystallization peak. The minimum intensity of XRD diffraction of the (101) lattice peak at $2 \theta$ equal to $18^{\circ}$ represents the amorphous cellulose regions and the maximum intensity of the (002) lattice peak at $2 \theta$ equal to $22^{0}$ represents crystalline cellulose regions. Hemicellulose and lignin have been determined to have diffractograms similar to amorphous cellulose [58], giving wide unspecific peaks, which may affect the results.

\section{CONCLUSIONS}

Structural changes of pretreated bamboo mainly came from the combination of microwave disruption and removal of lignin and hemicellulose in water medium under heating pretreatment. Generally, weight loss of pretreated samples tended to increase after more severe pretreatment condition. FTIR spectras indicated that no functional group changes occured after microwave pretreatment, even though there was slight shifting in wave number of functional groups and a decrease in band absorbancy. Absorbance of $1327 \mathrm{~cm}^{-1}$ (syringyl) was lower than that of guiacyl $\left(1257 \mathrm{~cm}^{-1}\right)$ shows that syringil propane unit was lower than that of guaiacyl 
lignin under microwave heating. After bamboo was irradiated for $12.5 \mathrm{~min}$ at $330 \mathrm{~W}$, monoclinic structure of cellulose transformed to triclinic structure. The disruption of the structure of the cell wall increased the accessibility of cellulase to lignocellulose. Except microwaving for $5 \mathrm{~min}$ $(330 \mathrm{~W})$, the microwave heating caused carbon and oxygen increasing compared to untreated samples. The crystallinity index leads to increase after pretreatment suggested the selective degradation of amorphous components. The crystallinity index at irradiation time for $5 \mathrm{~min}(330 \mathrm{~W}$ and $550 \mathrm{~W}$ ) was lower than that of the other irradiation time.

\section{ACKNOWLEDGMENT}

This study is part of PhD thesis supported by the Ministry of Research and Technology (RISTEK), Indonesia through PhD scholarship, is gratefully acknowledged.

\section{REFERENCES}

[1] J. Littlewood, L.Wang, C. Turnbull, R.J. Murphy, “Techno-Economic Potential of Bioethanol from Bamboo in China", Biotechnology for Biofuels, vol.6, pp. 173, 2013.

[2] Z. Li, Z. Jiang, B. Fei, X. Liu, Y. Yu, "Bioconversion of Bamboo to Bioethanol Using the Two-Stage Organosolv and Alkali Pretreatment", BioResources. 7(4) (2012):5691-5699.

[3] P. Kant, "Should bamboos and palms be included in CDM forestry projects?", IGREC Working paper, No.IGREC-07:2010, Institute of Green Economy, New Delhi, 2010.

[4] N. Sathitsuksanoh, Z.Zhu, N.Templeton, J. Rollin, S. Harvey, Y.H.P. Zhang, "Saccarification of A Potential Bioenergy Crop, Phragmites Australis (Common Reed), by Lignocellulose Fractionation Followed by Enzymatic Hydrolysis at Decreased Cellulose Loadings", Ind.Chem.Res., vol 48, pp. 6441-6447, 2009.

[5] Y.-H.P.Zhang, "Reviving the Carbohydrate economy via multiproduct biorefineries", J.Ind.Mucrobiol.Biotechnol.vol.5, pp.367-375, 2008.

[6] M. Lobovikov, S. Paudel, M. Piazza, H. Ren, J. Wu, "World bamboo resources. A thematic study prepared in the framework of the global forest resources assessment 2005, Non Wood Forest Products 18, Food and Agricultural Organization of the United Nations, Rome, pp. 73, 2007

[7] M.Gelbe, G.Zacchi, "Pretreatment of Lignocellulosic Materials for Efficient Bioethanol Production",. Adv.Biochem.Eng./Biotechnol., 108 41-65, 2007.

[8] C. Cara, E. Ruiz, J.M. Oliva, F.Saez, E.Castro, "Conversion of Olive Tree Biomass into Fermentable Sugars by Dilute Acid Pretreatment And Enzymatic Saccarification", Bioresource Tech. vol.99, pp.18691876,2008

[9] C. Conde-Mejía, A. Jiménez-Gutiérrez, M. El-Halwagi, “A Comparison of Pretreatment Methods for Bioethanol Production from Lignocellulosic Materials", Process Safety and Env. Protec. vol. 90(3) pp.189-202, 2012.

[10] W-H.Chen,Y-J.Tu, H-K. Sheen, "Disruption of Sugarcane Bagasse Lignocellulosic Structure by Means of Dilute Sulfuric Acid Pretreatment with Microwave-Assisted Heating", Applied Energy, vol. 88(82), pp. 2726-2734, 2011.

[11] Z.H. Hu, Z.Y. Wen, "Enhanching Enzymatic Digesbility of Switchgrass by Microwave-Assisted Alkali Pretreatment", Biochem. Eng. J., vol. 38(3), pp. 369-378, 2008.

[12] Z. Zhang, Y. Shan, J. Wang, H. Ling, S. Zang, W. Gao, Z. Zhao, H. Zhang, "Investigation on the Rapid Degradation of Congo Red Catalyzed by Activated Carbon Powder under Microwave Irradiation, J. of Hazardous Materials, vol.147(1-2), pp. 325-333, 2007.

[13] S.M.Nomanbhay, "Microwave-Assisted Alkaline Pretreatment and Microwave Assisted Enzymatic Saccharification of Oil Palm Empty Fruit Bunch Fiber for Enhanced Fermentable Sugar Yield". J. of Sustainable Bioenergy Systems, vol. 3(1), pp.7-17, 2013.

[14] J. Xiong, J.Ye, W.Z.Liang, P.M. Fan, "Influence of Microwave on the Ultrastructure of Cellulose I", Journal of South China University of Technology, vol. 28(3), pp. 84-89, 2000.
[15] J. Azuma, F. Tanaka, T. Koshijima, "Enhancement of Enzymatic Susceptibility of Lignocellulosic Wastes by Microwave Irradiation, J. of Fermentation Tech., vol. 62(4), pp.377-384, 1984.

[16] J. Xu, H. Chen, Z. Kadar, A.B. Thomsen,"Optimization of Microwave Pretreatment on Wheat Straw for Ethanol Production", Biomass and Bioenergy, vol. 35, pp. 3859-3864, 2011.

[17] P. Binod, K. Satyanagalakshmi, R. Sindhu, K.U. Janu, R.K. Sukumaran, A. Pandey, "Short duration microwave assisted pretreatment enhances the enzymatic saccharification and fermentable sugar yield from sugarcane bagasse", Renewable Energy, vol. 37(1), pp.109-116, 2012.

[18] D.R. Kheswani, "Microwave Pretreatment of Switchgrass for Bioethanol Production", PhD thesis, North Carolina State University, Raleigh, North Carolina, 2009.

[19] S.Ravoof, K. Pratheepa, T.Supassri, S. Chittibabu,"Enhancing enzymatic hydrolysis of rice straw using microwave assisted nitric acid pretreatment”. Int. J. Med. Biosci., vol.1(3), pp. 13-17, 2012.

[20] R. Singh, S. Tiwari, M. Srivastava, U. Mina, "Effect of Combination of Microwave and Hydrogen Peroxide (H2O2) Pretreatment on Enzymatic Saccarification of Rice Straw". I. J. of Env. Eng. and Management, vol. 4(5), pp.529-542, 2013a.

[21] R. Singh, S. Tiwari, M. Srivastava, A. Shukla, "Performance Study of Combined Microwave and Acid Pretreatment Method for Enhancing Enzymatic Digestibility of Rice Straw for Bioethanol Production", Plant Knowledge J., vol. 2(4), pp.157-162, 2013 b.

[22] R. Singh, S. Tiwari, M. Srivastava, A. Shukla, "Microwave-assisted Alkali Pretreatment of Rice Straw for Enhancing Enzymatic Digestibility", J. of Energy, pp.1-7, 2014.

[23] F. Pang, S. Xue, S. Yu, C.Zhang, B. Li, Y. Kang, "Effects of Microwave Power and Microwave Irradiation Time on Pretreatment Efficiency and Characteristics of Corn Stover Using Combination of Steam Explosion and Microwave Irradiation (SE-MI) Pretreatment", Bioresour Technol., vol.118, pp. 111-119. 2012.

[24] J-i Azuma, J.H. No, M. Isaka, T. Koshijima, "Microwave irradiation of lignocellulosic materials: IV. Enhancement of enzymatic susceptibility of microwave-irradiated softwoods", Wood research, pp. 7113-24, 1985.

[25] K.K. Pandeya, A.J.Pitman, "FT IR Studies of the Changes in Wood chemistry Flowing Decay by Brown-rot and White-rot Fungi. Int. Biodeterioration \& Biodegradation", vol.52, pp.151-160, 2003.

[26] H.K.Zhao, J.H. Kwak, Y.Wang, J.A. Franz, J.M.White, J.E. Holladay, "Effects of Crystallinity on Dilute Acid Hydrolysis of Cellulose by Cellulose Ball-Milling Study", Energy \& Fuels, vol. 20(2), pp. 807811, 2006.

[27] Focher B, MT. Pala, M. Canetti, G Torri, C. Cosentino, G. Gastaldi, "Structural Differences between Non-Wood Plant Cellulose: Evidence from Solid State NMR, Vibrational Spectroscopy and Xray diffractometry", Ind Crops Products, vol.13, pp.193-208, 2001.

[28] M.Wada, T.Okano, J. Sugiyama, "Allomorphs of Native Crystalline Cellulose I Evaluated by Two Equatorial d-spacings", J.Wood Science, vol. 47, pp.124-128, 2001.

[29] M. Ahtee, T. Hattula, J. Mangs, T. Paakkari, "An X-ray diffraction method for determination of crystallinity of wood pulp", Paperi Ja Puu, vol.8, pp.475-480, 1988.

[30] Z. Li, Z. Jiang, B. Fei, Y. Yu, Z. Cai, "Effective of microwave-KOH pretreatment on enzymatic hydrolysis of bamboo", J. of Sus. Bioenergy Systems, vol. 2, pp. 104-107, 2012.

[31] A. Goshadrou, K. Karimi, M.J. Taherzadeh, "Improvement of Sweet Sorghum Bagasse Hydrolysis by Alkali and Acidic Pretreatment", in Wood Renewable Energy Congress, 2011, p.374-380.

[32] S.A. Galema, "Microwave chemistry", Chemical Society Reviews 26(3), pp. 233-238,1997.

[33] V. Sridar, "Microwave Radiation as a Catalyst for Chemical Reaction", Current Science, vol 74(5), pp. 446-450, 1998.

[34] S.M. Nomanbhay, R. Hussain, K. Palanisamy, "Microwave-Assisted Alkali Pretreatment and Microwave Assisted Enzymatic Saccarification of Oil Palm Empty Fruit Bunch Fiber for Fermentable Sugar Yield", J. of Sus. Bioenergy System, vol. 3, pp.7-17. 2013.

[35] L.Wang, G. Han, Y. Zhang, Comparative Study of Composition Structure and Properties of Apocynum venetum Fibers under Different Pretreatment, Carbohydrate Polymer, vol 69(2), pp. 391397, 2007.

[36] K.K. Pandey, "Study of the Effect of Photo-Irradiation on the Surface Chemistry of Wood", Polymer Degradation and Stability, vol. 90(1), pp.9-20, 2005. 
[37] Y. Sun, L. Lin, H.B. Deng, J.Z. Li, B.H. He, R.C. Sun, "Structural Changes of Bamboo Cellulose in Formic Acid", Bioresources, vol. 3(2), pp. 297-315, 2008.

[38] D. Fengel, G. Wegener. Wood Chemistry, ultrastructure, reactions. Berlin \& New York: Walter de Gruyter, 1989.

[39] M.L. Nelson, R.T. O’Connor, "Relation of Certain Infrared Bands to Cellulose Crystallinity and Crystal Lattice Type. Part II A New Infrared Ratio for Estimation of Crystallinity in Cellululoses I and II". J.Appl.Polym.Sci., vol. 8, pp. 1325-1341, 1964.

[40] A. O'Sullivan, Cellulose: the Structure Slowly Unravels", Cellulose. 4, pp 173-207, 1997.

[41] J-F. Sassi, P.Tekely, H. Chanzy, "Relative susceptibility of the I $\alpha$ and I $\beta$ phases of cellulose towards acetylation", Cellulose, pp.7119-132, 2000.

[42] M. Wada, T. Okano, "Localization of I $\alpha$ and I $\beta$ Phases in Algal Cellulose Revealed by Acid Treatments", Cellulose, pp. 8183-188, 2001.

[43] N. Hayashi, M. Ishihara, J. Sugiyama, T. Okano, "The Enzymatic Susceptibility of Cellulose Microfibrils of The Algal-Bacterial Type and Cotton-Ramie Type", Carbohydrate Research, vol. 305, pp. 109116.1998a.

[44] N. Hayashi, M. Ishihara, J. Sugiyama, T. Okano, "Selective Degradation of Cellulose ia Component in Cladophora Cellulose with Trichoderma viride Cellulose", Carbohydrate Research, vol. 5 261-269, 1998b.

[45] W. Fatriasari, W.Syafii, N.Wistara, K.Syamsu, B. Prasetya. "The Characteristic Changes of Betung Bamboo (Dendrocalamus asper) Pretreated by Fungal Pretreatment”, Int. J. of Renewable Energy Dev. 3(2), pp. 133-143, 2014.

[46] E. Gumuskaya, M. Usta, "Dependence of Chemical and Crystalline Structure of Alkali Sulfite Pulp on Cooking Temperature and Time. Carbohydrate Polymers, vol. 65, pp.461-468, 2006.

[47] E.Gumuskaya, M. Usta, H.Kirci, "The Effects of Various Pulping Conditions on Crystalline Structure of Cellulose in Cotton Linters", Polymer Degradation and Stability, vol. 81, pp. 559-564, 2003

[48] J. Lu, P. Zhou, "Optimization of Microwave-Assisted $\mathrm{FeCl} 3$ Pretreatment Conditions of Rice Straw and Utilization of
Trichoderma viride and Bacillus pumilus for Production of Reducing sugar”, Bioresource Tech., vol.102(13), pp.6966-6971, 2011.

[49] T. Rezanka, K.Sigler, "Biologically Active Compounds of Semimetals", Phytochemistry, vol. 69 (3), pp.585-606, 2008.

[50] Z. Liu, B. Fei, (2013) Characteristics of Moso Bamboo with Chemical Pretreatment. [Online]. Available: http://www.intechopen.com/books/sustainable-degradation-oflignocellulosic-biomass-techniques-applications-andcommercialization/characteristics-of-moso-bamboo-with-chemicalpretreatment,

[51] N. Mosier, C. Wyman, B. Dale, R. Elender, Y.Y. Lee, M. Holtzapple, M. Landisch, "Features of Promising Technologies for Pretreatment of Lignocellulosic Biomass", Bioresource Tech.,vol. 96(6), pp. 673686, 2005.

[52] J.S. Bak, J.K. Ko, Y.H. Han, B.C. Lee, I.G. Choi, K.H. Kim, "Improved Enzymatic Hydrolysis Yield of Rice Straw Using Electron Beam Irradiation Pretreatment", Bioresource Tech., vol. 100(3), pp.1285-1290, 2009.

[53] S. Kim, M.T.Holtzapple,'Effect of Structural Features on Enzyme Digestibility of Corn Stover". Bioresource Tech., vol. 97(4), pp. 583591, 2006.

[54] T.H Kim, Y.Y Lee,"Pretreatment and Fractionation of Corn Stover by Ammonia Recycle Percolation Process", Bioresource Technol.,vol.97, pp.2007-2013,2005.

[55] J.P. O’Dwyer, L. Zhu, C.B. Granda, M.T. Holtzapple,’Enzymatic Hydrolysis of Lime-Pretreated Corn Stover and Investigation of The HCH-1 Model: Inhibition Pattern, Degree of Inhibition, Validity of Simplified HCH-1 Model”, Bioresource Tech., vol. 98(16), pp.29692977, 2007.

[56] S.Y. Oh, D.I. Yoo, Y. Shin, G. Seo. "FTIR Analysis of Cellulose Treated with Sodium Hydroxide and Carbon Dioxide", Carbohydrate Research, vol. 340(3), pp 417-428, 2005.

[57] L.-W. Lai, A.Idris, "Disruption of Oil Palm Trunks and Fronds by Microwave-Alkali Pretreatment", BioResources, vol. 8(2), pp.27922804, 2013

[58] Z. Gao, T.Mori, R. Kondo, "The Pretreatment of Corn Stover with Gloeophyllum trabeum KU-41 for Enzymatic Hydrolysis", Biotechnology for Biofuels, vol. 5 (28), pp. 1-11. 2012. 